\title{
ELŻBIETA WELKER
}

Polish Naval Academy, Gdynia, Poland

JAN REDA

Instytut of Geophysics of Polish Academy of Sciences, Warsaw, Poland

ANDRZEJ PALKA

OPTIMUM, Warsaw, Poland

\section{MAGNETIC REPEAT STATION NETWORK ON THE BALTIC SEA - WHY SO NEEDED?}

\begin{abstract}
The development of navigation systems requires more and more accurate base data. Currently, attention is paid to utilization of geophysical fields - gravitational and magnetic ones - for navigation purposes. The Earth's magnetic field distribution - both onshore and offshore - is complicated and variable in time. Hence, it is essential to precisely know the secular variations in the area of interest. In the case of Baltic Sea, this involves establishing (re-establishing) of a marine network of secular points (repeat stations) and regular magnetic measurements of the three independent components of the Earth's magnetic field. Such measurements require equipment that ensures not only high stability, but also information about sensors' orientation in relation to geographic north and to the level. This article presents a new project of the Baltic network of repeat stations and gives a solution for the instruments usable for quasi-absolute magnetic measurements.
\end{abstract}

\section{Keywords:}

Earth's magnetic field, marine magnetic repeat stations, secular geomagnetic field changes.

\section{INTRODUCTION}

The magnetic field of the Earth is highly variable in time. The direction of changes and their amount depend on many factors, both internal and external. The long-term changes are called secular changes. The study of the Earth's magnetic 
field is necessary, e.g., for building global geomagnetic field models [Barraclough, De Santis, 2011; Sas-Uhrynowski, 1990].

On land, magnetic measurements are made on secular points of the country's magnetic network established for this purpose. Systematic measurements of three independent components (at present, these are declination $D$, inclination $I$ and modulus of total intensity vector $F$ ) make it possible to determine the trend and amount of these changes [Żóltowski, 1978]. Measurements of the vector $\mathbf{F}$ modulus by means of proton magnetometer are direct and give a current momentary value at the measurement point. Calculation of the momentary declination and inclination value necessitates measurements by means of a theodolite with magnetic sensor - flux-gate.

On sea, the measurements are complicated not only because of instability of the measuring instrument and ferromagnetic elements present at the vessel, but mainly because of the problems with keeping the probe's orientation at a certain fixed direction relative to the geographical north. New gyrocompasses and marine magnetometers partly eliminate these problems, but what always remains is a problem with absolute measurements. In the 1990s, there appeared a new navigational device, which makes use of geomagnetic field components. These are the so-called flux-gate type (also called electronic) compasses, more and more frequently used as a source of information about the course. This means that the knowledge on declination on sea becomes now more important than it was earlier [Felski, Przepióra, 1995].

Geophysical fields are now more and more often utilized in new navigation technologies, especially when it is not possible to apply the GNSS. This concerns mainly the anomalous field. Magnetic anomalies are the regions in which differences between the geomagnetic component values obtained from direct measurement (local model of geomagnetic field) and calculated on the basis of the normal geomagnetic field are large, i.e., few times greater than the annual variations of this component [Welker, 2015a, 2015b]. The normal field values are calculated from coefficients determined every 5 years spherical harmonic analysis for the global geomagnetic field. At present, it is the IGRF (International Geomagnetic Reference Field) model that is most frequently used; it is developed on the basis of all magnetic land, sea and satellite data available over the world [Welker, 2013].

\section{BRIEF HISTORY OF MAGNETIC MEASUREMENTS ON THE BALTIC SEA}

First measurements of magnetic declination for the needs of navigation on the Baltic were already made in the second half of the XVI century. The results of 
XVII century systematic measurements at magnetic points in the vicinity of Gdańsk (made by Jan Heweliusz) provided a possibility of determining the first secular changes and their interpretation [Welker, 2015a]. The magnetic data obtained during hydrographic (bathymetric) measurements on the turn of XIX and XX centuries have lead to the publication, in 1901, of the first isogon maps of the Baltic. In the XX century, measurements on the sea were made occasionally by scientists from Sweden, Denmark, Germany, and also, since the 1930s, from Poland.

Because of the lack of suitable instruments, the measurement of all geomagnetic field components was impossible. It was only after the Second World War that systematic magnetic measurements on land, in air and in water became feasible, owing to the construction of proton magnetometers and fluxgate sensors [Welker, 2013].

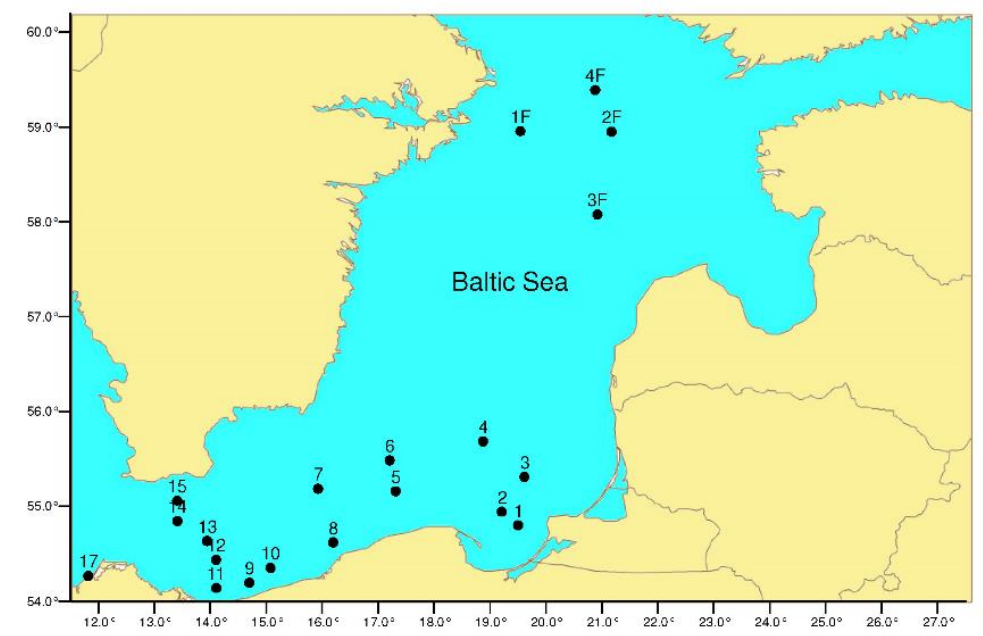

Fig. 1a. Distribution of repeat stations on the Baltic Sea for measurements in 1982-1988 (Source: Sas-Uhrynowski et al., 2000)

The first attempts at establishing the repeat stations on the Baltic Sea were undertaken in the 1980s (Fig. 1a, 1b) [Mroczek, Sas-Uhrynowski, 1986; SasUhrynowski, 1990] in the framework of a large project, comprising magnetic measurements at profiles deployed around the whole sea area. The project was carried out by the St. Petersburg Branch of the Institute of Terrestrial Magnetism, Ionosphere and Radiowave Propagation of the Russian Academy of Sciences IZMIRAN, and the Institute of Geodesy and Cartography in Warsaw (IGiK). As a result of many-year (1970-1990) measurements and their analysis, the first complex magnetic chart of the Baltic Sea was obtained [Sas-Uhrynowski et al., 
2001]. However, one should keep in mind the abilities of the instruments used for localizing the point as well as geomagnetic field recording at that time.

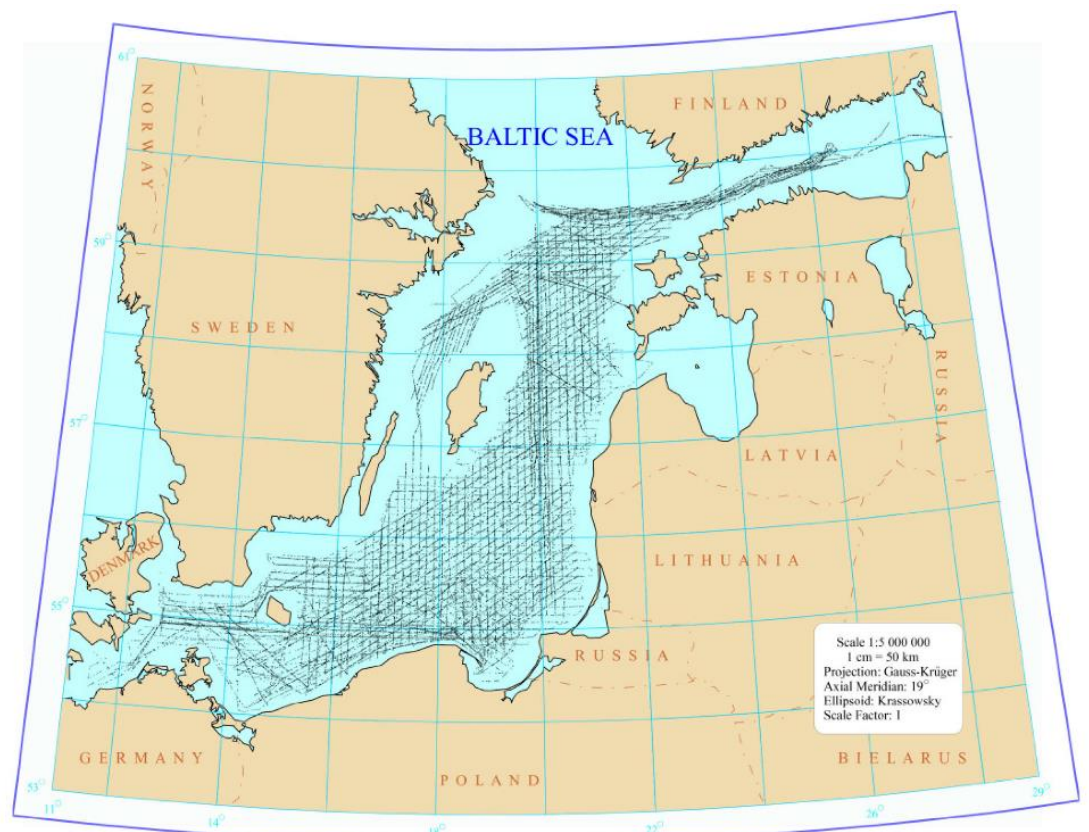

Fig. 1b. Distribution of repeat stations on the Baltic Sea for measurement profiles in 1970-1990. (Source: Sas-Uhrynowski et al., 2000)

\section{UPDATING OF MARINE RESULTS ON THE BALTIC}

Up to now, the updating of magnetic measurements on the Baltic has been made using magnetic field data from observatories situated along the shores (Fig. 2) [Sas-Uhrynowski et al., 2001]. The use of geomagnetic field or its anomalies for marine navigation, notably for submarines, demands that the magnetic field, as well as its distribution and changes, be known on the whole sea area with high accuracy [Kasyanenko, Sas-Uhrynowski, 1996; Uhrynowski, 1992].

The present-day navigation systems require that the isolines of geomagnetic field component were determined with high accuracy. This necessitates the examination of the geomagnetic field distribution at a given sea area, and systematic magnetic measurements for monitoring its changes. Hence, it would be advisable 
to deploy a repeat station network at the Baltic Sea (on the level of the water or at the bottom) and systematically perform magnetic measurements. To enable complex analyses, it would be best to have a possibility of making the absolute measurements at these marine repeat stations. As we already mentioned, there is no problem with measuring of the total geomagnetic component $F$, but the problem is with positioning the $X Y$ sensors in the geographic north direction, and keeping their stability. During preparation for accessing the EU project BONUS, attempts were made to develop a method for stabilizing repeat stations at the Baltic's bottom. Such stations, located at various places of the Baltic, would serve for magnetic measurements by means of geomagnetic field recording instruments. The variations so recorded could be transformed, upon developing an appropriate method, into quasi-absolute measurements.

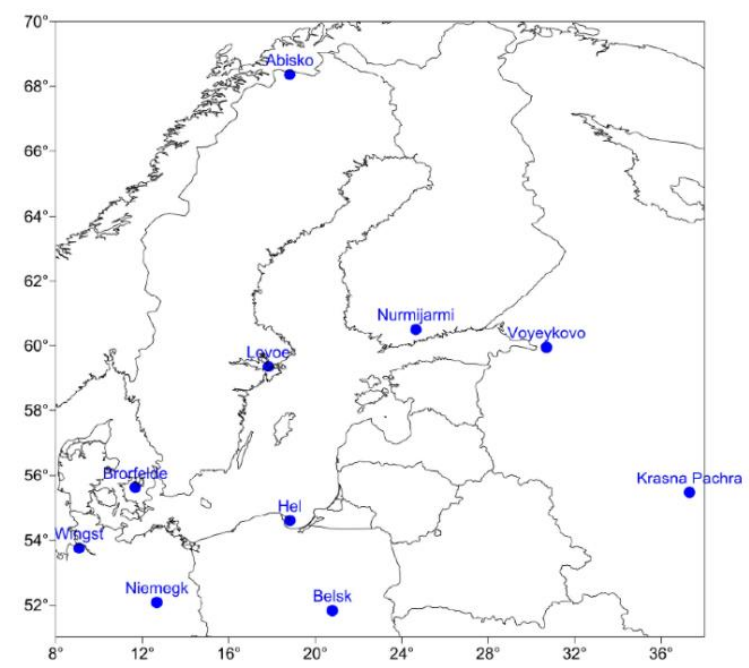

Fig. 2. Magnetic observatories around the Baltic Sea. (Source: Sas-Uhrynowski A., 1992).

\section{INSTRUMENTATION}

The measurements of geomagnetic field components in a magnetic observatories or an on-land secular points are made by means of a DI-fluxgate magnetometer to determine inclination and declination. At the same time, the modulus of 
the total intensity vector $F$ is measured by a proton magnetometer. The DI-fluxgate magnetometer consists of a single fluxgate sensor mounted on a non-magnetic theodolite. The measurement of declination and inclination by means of a DI-fluxgate magnetometer is a series of measurements of the magnetic field component in a few, strictly defined positions of the magnetometer's sensor. In the course of the measurement, it is necessary to ensure a very stable fixing and leveling of the theodolite. Also, the direction toward the geographical north must be known with high accuracy (single angular seconds). At a magnetic observatory, the geographical north direction for every base pillar is known from the earlier astronomical observations relating to known control point. During measurements at land secular points, the geographical north direction is also determined from the observations of the Sun or Polar Star.

During measurements on sea, likewise on-land ones, there is no problem with measuring the modulus of the total intensity vector $F$ by means of a proton magnetometer. It is impossible, however, to use the DI-fluxgate magnetometer for determining declination and inclination of the Earth's magnetic field. At the sea surface, stable positioning of a theodolite for a series of measurements is unattainable. At the sea bottom, the conditions for using the DI-fluxgate do not exist, because it is impossible to determine the geographic north the methods applicable at land. Over ten years ago, the geomagnetic field measurements on the Baltic were made with the use of sea-bottom magnetometers placed on the sea bottom [Marianiuk et al., 2007]. The recordings yielded a relatively accurate picture of the geomagnetic field changes (Fig. 3).

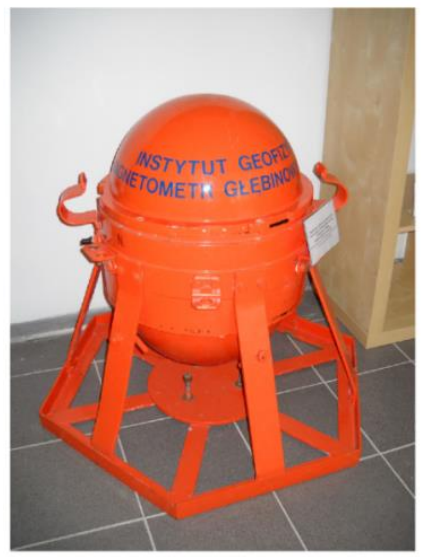

Fig. 3. Sea-bottom magnetometer for magnetic measurements at the Baltic Sea bottom. (Source: Marianiuk J. et al., 2007) 
It seems that in sea measurement conditions, the only possibility is to use a magnetometer with three flux-gate sensors in mutually orthogonal orientation, that have previously been calibrated in a magnetic observatory (Fig. 4). Such quasi-absolute measurements will not be as precise as the measurements in the geomagnetic observatory conditions, but will be precise enough for compiling an accurate magnetic chart of the Baltic.
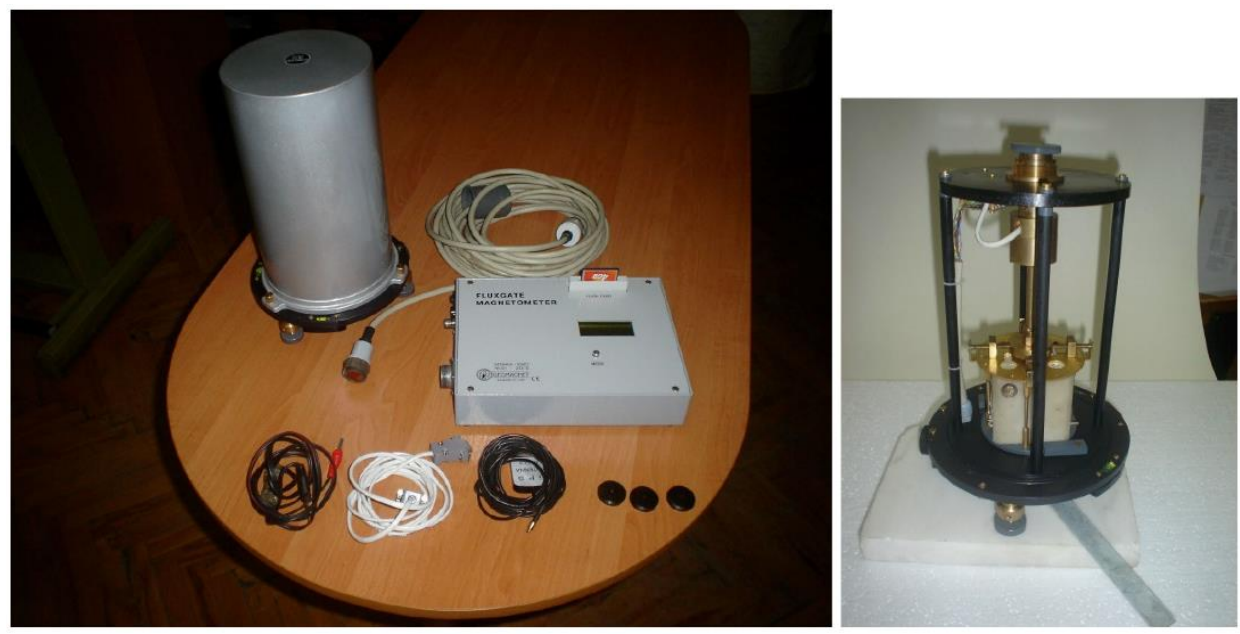

Fig. 4. Flux-gate magnetometer to be used in marine measurements. (Source: Marianiuk J. et al., 2007)

The measurements can be made at nonmagnetic platforms, in the form of, e.g., concrete basements, previously prepared at the sea bottom (Fig. 5). Precise leveling of the sensors will be ascertained by a measurement head with automatic gravitational leveling. The most difficult problem is how to determine the geographical north. Once the north direction is established, the measurement head can be turned according to this direction, or the actual positioning of the measurement head is to be measured. The determination of the geographical north can be made by means of a gyroscope. Instruments of such type are used in underground geodetic surveys in tunnel building works. The simplest way would be to rigidly fix together the gyroscope and the magnetometer's head. In such a case, however, it would be necessary to determine and take into account the corrections resulting from geomagnetic field distortions due to the gyroscope. 


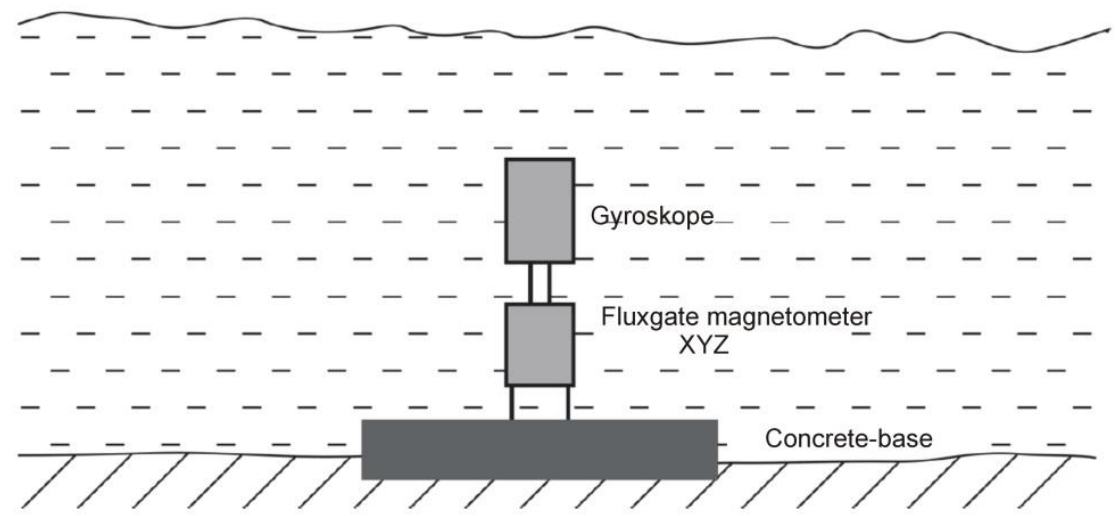

Fig. 5. Proposed manner of magnetic point stabilization on the Baltic Sea bottom

Another technical problem is to design a flux-gate magnetometer suitable for work in the conditions existing at the sea bottom. The magnetometer should assure a good orthogonality of the component measurements, good linearity of each of the three sensors, and large stability in time. Additionally, a method should be developed for calibration of the magnetometer measurement head at the geomagnetic observatory, and temperature corrections should be determined. The linearity of sensors is particularly important in the case of using the magnetometer in the variant without mechanical positioning towards the geographical north.

From recent comprehensive marine geomagnetic measurements in the Baltic Sea (1970-1990), angular components (inclination and declination) and linear components of the magnetic field can be obtained with an accuracy of 12-20 arcminutes and 25-40 nT, respectively. At present, using modern instrumentation (flux-gate and proton magnetometers), under field conditions, the accuracy of absolute measurements for the length component of the total magnetic intensity vector $\mathbf{F}$ of 1-3 nT, and for declination better than 1 arcminute can be achieved. Pessimistic (careful) estimate of the accuracy of measurements at sea will be 2-3 times worse, i.e. it will be about 5 nT for $F$ and 2-3 arcminutes for declination. Such accuracy would be quite satisfactory for the preparation of marine magnetic maps. The main source of errors of obtained values of the magnetic field components is the determination of the base values and the setting of the $\mathrm{X}$ probe towards the true north. Only real measurements at the test marine point will allow verification of these assumptions. The accuracy of data depends also on the stabilization of the marine repeat station. 


\section{PROJECT OF MAGNETIC REPEAT STATION NETWORK}

On the basis of the existing magnetic charts of the Baltic Sea [Sas-Uhrynowski et al., 2000], the network of magnetic repeat stations should be designed. These can include the secular points located on islands and shores, selected so as to enable safe access and mooring. The points should be located far away from large geomagnetic field anomalies and, if possible, their sites should be confronted with the bathymetric map of the Baltic. An exemplary project of such a network (Fig. 6), composed of 6 points, was described by Welker [2015a] and presented in 2013 on the International MagNetE Workshop in Budapest [Welker, 2015b].

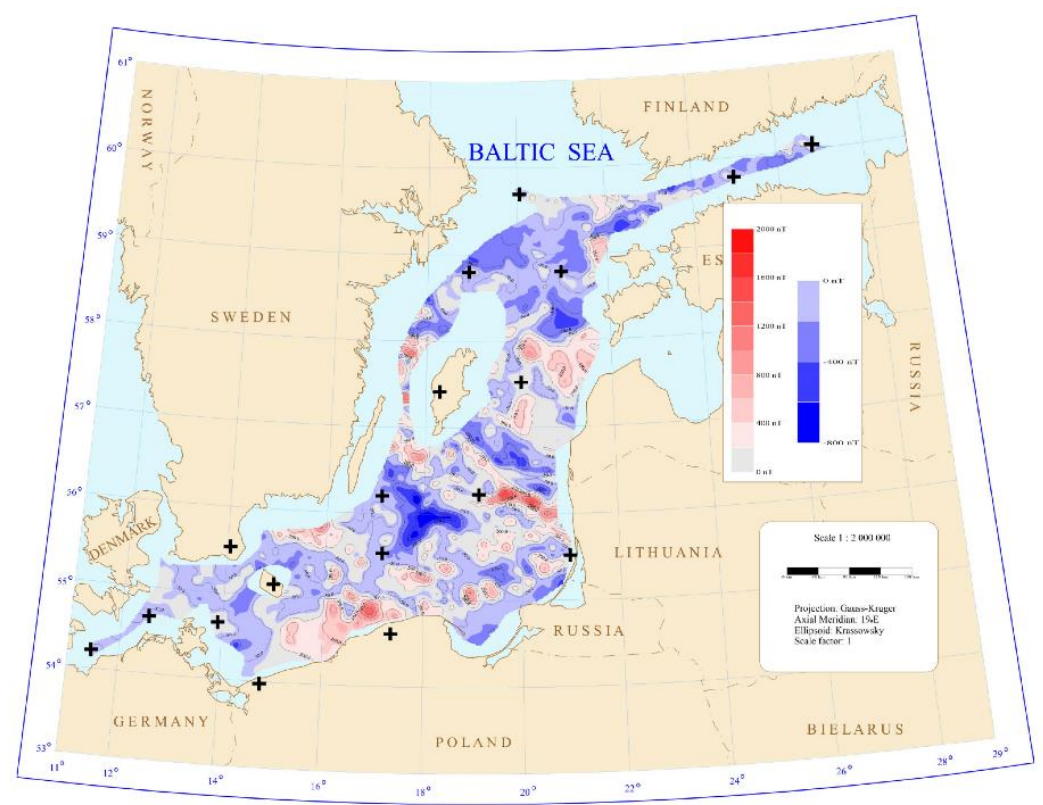

Fig. 6. Project of magnetic repeat station network on the background of a map of $F$ anomalies. (Source: Sas-Uhrynowski et al., 2000).

Measurements of the three independent geomagnetic components at the repeat station of the marine network should be repeated at least every 2-3 years. On their basis, a model of secular changes of the geomagnetic field on the Baltic Sea area would be developed, to provide a possibility of systematic updating of marine magnetic measurements and maps. At present, as we already mentioned, 
such an updating can only be made on the basis of the field changes recorded in magnetic observatories distributed around the Baltic. Along with the measurements on secular points, measurements on characteristic points selected on the basis of maps (anomalies, important or uncertain locations, etc.) should be repeated too.

\section{CONCLUSIONS}

As mentioned above, the progress in the development of measuring instruments, both navigational and geophysical, seems to force the need and give a possibility of acquiring more detailed geophysical data aiding the navigational systems. Owing to the existing maps from the Atlas of the Baltic Magnetic Charts, it is possible to better design the magnetic repeat station network and thus obtain an accurate model of secular changes of the geomagnetic field on the area. To verify the charts of the atlas, the magnetic measurements should be repeated on selected profiles or at sites of characteristic changes in the geomagnetic field.

To carry the task into effect would certainly be associated with some costs relating to the design and construction of the measurement equipment and stabilization of secular points at the Baltic bottom. Also, a vessel would be needed to transport the equipment and suitably place it in a chosen site. The gravity measurement and the measurement of a modulus of the total intensity vector of the geomagnetic field are least problematic. The most troublesome will be to make a proper positioning of the sensor for the measurement of geomagnetic components $X, Y$ and $Z$, and to relate the measurement sensor orientation with the geographic north direction.

For the development of science and recognition of the specificity of geo-

physical fields on the Baltic Sea area, it is worth undertaking this challenge; the more so, since the results of geomagnetic field obtained from satellite measurements considerably generalize the field pattern, losing all regional and local anomalies, while the latter ones have direct influence on the precision of navigation process [Rotanova et al., 2000; Internet page of mission SWARM].

\section{Acknowledgements}

The paper was written in the framework of cooperation between the Institute of Geodesy and Cartography; Institute of Geophysics, Polish Academy of Sciences; and Polish Naval Academy. The authors are grateful to Professor Andrzej Sas-Uhrynowski for shearing 
his many-year experience in the field of marine geomagnetism. Knowledge and experience of the staff of the Geophysical Observatory of the Institute of Geophysics, PAS, were also very helpful. Thanks are also due to Professor Andrzej Felski for creating the atmosphere and conditions enabling popularization of the results of geomagnetic field research and their use in navigation.

\section{REFERENCES}

[1] Barraclough D. R., Santis A. de, Repeat Station Activities, Chapt. 3, [in:], Geomagnetic Observations and Models, eds. M. Mandea, M. Korte, IAGA Special Sopron Book, Series 5, Springer Science+Business Media B.V., 2011, DOI: $10.1007 / 978$ -90-481-9858-0_3.

[2] Felski A., Przepióra T., The analysis of the accuracy of the electronic compass, 'Scientific Bulletin of the Polish Naval Academy', 1995, No. 4, pp. 23-30.

[3] Kasyanenko L. G., Sas-Uhrynowski A., The delimitation of secular changes of the geomagnetic field on seas and oceans (in Polish), 'Prace IGiK', 1995, No. 91.

[4] Marianiuk J., Jóźwiak W., Neska A., Neska M, Underwater magnetometer MG-01/2003 for geomagnetic offshore soundings, XII IAGA Workshop on Geomagnetic Observatory Instruments, Data Acquisition and Processing, Publs. Inst. Geophys. Pol. Acad. Sc., 2007, C-99 (398), pp. 87-92.

[5] Mroczek S., Sas-Uhrynowski A., Measurement on sea magnetic secular points on Baltic (in Polish), 'Biuletyn Informacyjny BOINTE Geodezji i Kartografii', 1986, No. 1, pp. 28-35.

[6] Rotanova N. M., Odintsov S. D., Sas-Uhrynowski A., Welker E., The magnetic anomaly field over Poland and adjacent regions by using MAGSAT satellite data, 'Acta Geophysica Polonica', 2000, Vol. 48 (2), pp. 223-240.

[7] Sas-Uhrynowski A., Wpły The influence of the accuracy of the location of the secular-sea point on results of magnetic delimitations (in Polish), 'Prace IGiK', 1990, Vol. 37, No. 1-2.

[8] Sas-Uhrynowski A., Welker E., Demina I., Kasyanenko L., Vector magnetic survey on the Baltic Sea by schooner 'Zarya', Institute of Geodesy and Cartography, Warsaw, monographic series, 2001, No. 1, pp. 1-108.

[9] Sas-Uhrynowski A., Welker E., Diomina I., Kasyanenko L. The map collection of the geomagnetic field of Baltic, 'Prace IGiK', 2000, No. 100, pp. 9-24.

[10] Sas-Uhrynowski A., Secular changes of the magnetic field of the Earth in Poland in years 1971-1990 (in Polish), 'Prace IGiK', 1992, No. 87, pp. [13-19]

[11] Welker E., Manners of acquiring of the information on elements of the magnetic field of the Earth and their utilization in the geodesy and the navigation (in Polish), 'Prace IGiK', monographic series, 2013, No. 17. 
[12] Welker E. (2015a), Polish magnetic measurements in the Baltic — history and prospects, 'Zeszyty Naukowe Akademii Marynarki Wojennej', 2015, No. 2, pp. 75-85.

[13] Welker E. (2015b), Magnetic measurements on the Baltic Sea - current needs and possibilities, 7th MagNetE Workshop 'EUROPEAN GEOMAGNETIC REPEAT STATION SURVEY', 2014-2015, 16-18 September, Budapest.

Received August 2016

Reviewed March 2017

Published 03.07.2017

\title{
ELŻBIETA WELKER
}

Polish Naval Academy

Śmidowicza 69 Str., 81-127 Gdynia, Poland

e-mail:e.welker@amw.gdynia.pl

\section{JAN REDA}

Instytut of Geophysics of Polish Academy of Sciences

64 Księcia Janusza Str., 01-452 Warsaw, Poland

e-mail: jreda@igf.edu.pl

\author{
ANDRZEJ PALKA \\ OPTIMUM \\ 4 Suwak Str., 02-676 Warszawa, Poland \\ e-mail: info@optimum.com.pl
}

\section{STRESZCZENIE}

Rozwój systemów nawigacyjnych wymaga posiadania coraz dokładniejszych danych. Dotyczy to również znajomości naturalnych pól fizycznych Ziemi, które są postrzegane jako niezwykle użyteczne dla nawigacji, zwłaszcza grawitacyjne oraz magnetyczne. Rozkład pola magnetycznego Ziemi jest bardzo zróżnicowany przestrzennie, a ponadto jest zmienny w czasie - tak na lądzie jak i we wszechoceanie. Stąd tak istotna jest dokładna znajomość jego rozkładu, a także zmian wiekowych. W przypadku Morza Bałtyckiego wymagałoby to ustanowienia (wznowienia) sieci punktów wiekowych na morzu i regularnych pomiarów trzech składowych pola magnetycznego Ziemi w tychże punktach. Tego rodzaju pomiary wymagają odpowiedniego sprzętu, gwarantującego wysoką stabilność czujników, ale również wymagają sensorów zapewniających dokładną orientację urządzenia pomiarowego względem kierunku geograficznego oraz pionu. W artykule przedstawiono projekt Bałtyckiej Sieci Punktów Referencyjnych oraz propozycje rozwiązań technologicznych do budowy urządzeń zapewniających quasi-absolutne pomiary pola magnetycznego na dnie morza. 